\title{
Applications of geographic information systems in studying changes in groundwater quality and soil salinity in Sohag Governorate
}

\author{
Salah Hassanien Abd El-Aziz *, Mohsen A. Gameh, Ahmed Ghallab, Ibrahim H. Bakeer
}

Department of Soils \& Water, College of Agriculture, Assiut University Assiut, Egypt

\section{Article Info}

Received : 24.11.2017

Accepted : 09.04.2018

\begin{abstract}
Sohag governorate is a narrow long strip of a cultivated valley located in upper Egypt. Groundwater and soil samples were collected along the Nile river, starting form the southern border to the northern border of Sohag governorate to assess the groundwater quality and soil salinity between 1991 and 2006. The obtained data reveal that the electrical conductivity of well waters $\left(\mathrm{EC}_{\mathrm{w}}\right)$ was classified to four classes $(250-750,750$ 2250, 2250-5000 and greater than $5000 \mu \mathrm{S} / \mathrm{cm}$ ). The results showed an increase in the groundwater salinity within 15 years, especially in the first class where it increased from $9 \%$ in 1991 to $14 \%$ in 2006 but it raised from $17 \%$ in 1991 to $37 \%$ in 2006 for the third class. The surface and subsurface soil layers showed an increase trend in the soil salinity from 1991 to 2006. The soil salinity increased with depth from 1991 to 2006. The groundwater $\mathrm{pH}$ values changed due to the changes in their salt content from 1991 to 2006. The $\mathrm{pH}$ values of the surface and subsurface soil samples also changed from 1991 to 2006 that may be due to the changes in salt content of well waters. Cations and anions of the groundwater increased from 1991 to 2006. The groundwater SAR decreased for the first class (0-10) from $89 \%$ in 1991 to $83 \%$ in 2006 but increased for the second class (>10) from $11 \%$ in 1991 to $17 \%$ in 2006 . The groundwater RSC for the first and third classes changed from 91 and 3 \%, respectively, in 1991 to 83 and 11\%, respectively, in 2006. The increase in the high class of RSC may limit the use of these waters in irrigation. Thus, the irrigation with such water might affect the permeability of soil and cause infiltration problems.
\end{abstract}

Keywords: Groundwater quality, soil salinity, geographic information systems.

(C) 2018 Federation of Eurasian Soil Science Societies. All rights reserved

\section{Introduction}

Egypt lies in the arid region. Most of agricultural expansion areas are sandy soils which have poor physical and chemical properties, especially low water retention. One of the ways to overcome the increase of population in Egypt is to cultivate these soils. The expansion in the new areas needs more enough water to irrigate these soils. Saline soils are mostly located in arid and semi-arid regions. One of the conditions for the presence or formation of saline soils is the high evaporation, which greatly exceeds the precipitation. Soil salinity caused by natural or human-induced processes is a major environmental hazard. Crop growth reduction due to soil salinity is generally related to the soil solution osmotic potential of the root zone. As the soil salinity level increases, the plant must spend more energy to take up water from the same soil water content (Al-Khaier 2003; Bakeer 2008; Sayed, 2013). Salinization is of a great danger for arid and semi-arid irrigated agriculture. Without taking care, the salinity will have a negative impact on soil productivity and crop yields and lead to ecological degradation of land and water resources (Hillel, 2000).

\footnotetext{
${ }^{*}$ Corresponding author.

Department of Soils \& Water, College of Agriculture, Assiut University Assiut, Egypt

Tel.: +20882143282

e-ISSN: 2147-4249
}

E-mail address: abdelazizsh@yahoo.com DOI: $10.18393 /$ ejss.416675 
Groundwater is considered the second major source of irrigation water in upper Egypt after the Nile water. The newly cultivated desert areas depend mainly up on the groundwater for irrigation. The groundwater in some cases has a poor quality and contains enough salts to significantly alter the physical and chemical properties of soils and even to make growing crops rather difficult.

Use of poor-quality groundwater has become inevitable for irrigation to compensate the rapid increase of water demands in many arid and semiarid regions. Salinity and sodicity are the principal soil and water quality concerns in such areas. Many saline-sodic and sodic soils have saline or saline-sodic subsurface drainage waters (Qadir et. al., 2001)

Monitoring the groundwater quality, soil salinity and the efficiency of remedial efforts is very much needed in upper Egypt. Geographic information system (GIS), as a new technique, is widely used nowadays as a rapid method for delineating soil boundaries and characterization of soil units. GIS is used an important tool in monitoring and mapping of water quality and land evaluation (Yunus et al., 2003; Bakeer, 2008; Albaji et al., 2010 Ismail and Yacoub, 2012). The combination between remote sensing and GIS creates possible monitoring the soil salinity and waterlogging (Ghabour and Daels, 1993).

This study aims to evaluate the changes in the groundwater quality and soil salinity of Sohag governorate between 1991 and 2006, to help building the future strategic plans of agriculture in upper Egypt. GIS is used an important tool in monitoring and mapping these concerns.

\section{Material and Methods}

Sohag governorate lies in Upper Egypt. It is a narrow long strip of a cultivated valley and the total maximum length is about $96 \mathrm{Km}$, with a maximum width of about $25 \mathrm{~km}$. It is located between $26^{\circ}, 10^{\prime}, \& 26^{\circ}, 50^{\prime} \mathrm{N}$ and $31^{\circ}, 15^{\prime} \& 32^{\circ}, 50^{\prime} \mathrm{E}$ and consists of 11 counties. Groundwater and soil surface and subsurface samples were collected from transects along the Nile river, starting form the southern border to the northern border of Sohag governorate, covering a distance of about $96 \mathrm{~km}$ to identify the changes in the groundwater quality and soil salinity between 1991 (the results reported by Ghallab, 1995) and 2006 (the results of this study). It is very important to reassess the groundwater and surrounding soils quality after 15 years. One water sample was taken from each well water and two soil samples were collected from the surface $(0-25 \mathrm{~cm})$ and the subsurface layers $(25-50 \mathrm{~cm})$ from the area that the well covered. Groundwater and soil samples were collected from 35 locations in this governorate (Figure 1). Table 1 shows the particle size distribution of these soils. The collected groundwater and soil samples were analyzed for the major constituents using the standard methods of Jackson (1967, 1969), McLean (1982), Nelson (1982), Rhoades (1982), and Page et. al. (1986). This study is exploiting GIS for monitoring and mapping groundwater and salinity soils of Sohag governorate using Arcview, 9.1. The percentage of each class of soil or groundwater property in each figure was calculated based on the total number of groundwater or soil samples and was present in the key of each figure.

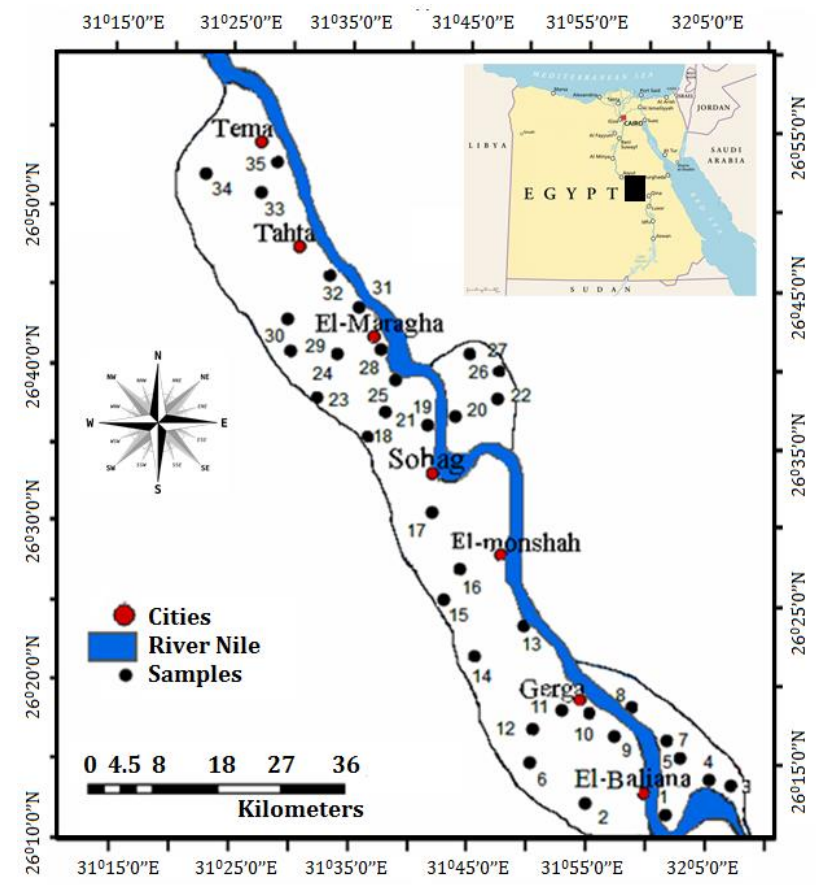

Figure 1. Locations of the colleted groundwater and soil samples. 
Table 1. Particle size distribution of the studied soils in the areas irrigated by groundwater

\begin{tabular}{|c|c|c|c|c|c|c|c|c|c|}
\hline \multirow{2}{*}{ No } & \multirow{2}{*}{ Location } & \multicolumn{4}{|c|}{ Surface $(0-25 \mathrm{~cm})$} & \multicolumn{4}{|c|}{ Subsurface $(25-50 \mathrm{~cm})$} \\
\hline & & Sand, $\%$ & Silt, $\%$ & Clay, \% & Class & Sand, $\%$ & Silt, $\%$ & Clay, \% & Class \\
\hline 1 & El -Balabesh Gobly & 55.088 & 24.386 & 20.526 & SCL & 55.088 & 24.386 & 20.526 & SCL \\
\hline 2 & El-Ghabat & 76.140 & 17.018 & 6.842 & SL & 73.333 & 18.456 & 8.211 & SL \\
\hline 3 & Awlad Salam Bahre & 55.088 & 35.333 & 9.579 & SL & 49.818 & 39.235 & 10.947 & $\mathrm{~L}$ \\
\hline 4 & Naknk & 60.702 & 37.930 & 1.368 & SL & 64.913 & 30.982 & 4.105 & SL \\
\hline 5 & Gazert Naknk & 74.737 & 21.158 & 4.105 & SL & 71.930 & 17.123 & 10.947 & SL \\
\hline 6 & Beat Alam & 77.544 & 18.351 & 4.105 & LS & 76.736 & 15.053 & 8.211 & SL \\
\hline 7 & El-Nosirat & 51.877 & 40.912 & 7.211 & SL & 53.685 & 35.368 & 10.947 & SL \\
\hline 8 & Nego Mazen Shark & 39.649 & 48.035 & 12.316 & $\mathrm{~L}$ & 50.877 & 36.807 & 12.316 & $\mathrm{~L}$ \\
\hline 9 & Gazert Bardes & 53.684 & 39.474 & 6.842 & SL & 56.491 & 33.930 & 9.579 & SL \\
\hline 10 & Gazert Bardes & 46.667 & 39.649 & 13.684 & $\mathrm{~L}$ & 48.070 & 35.509 & 16.421 & $\mathrm{~L}$ \\
\hline 11 & Gerga & 31.228 & 41.404 & 27.368 & $\mathrm{~L}$ & 35.438 & 33.088 & 31.474 & CL \\
\hline 12 & El-Rakakna & 48.877 & 31.965 & 19.158 & $\mathrm{~L}$ & 52.281 & 27.193 & 20.526 & SCL \\
\hline 13 & Awlad Hamza & 51.158 & 42.737 & 24.632 & $\mathrm{~L}$ & 24.210 & 32.631 & 24.632 & SiL \\
\hline 14 & Awlad Salama & 60.386 & 20.772 & 18.842 & SL & 53.684 & 21.684 & 24.632 & SCL \\
\hline 15 & El-Zara & 42.053 & 32.947 & 25.000 & $\mathrm{~L}$ & 46.667 & 30.070 & 23.263 & $\mathrm{~L}$ \\
\hline 16 & Awlad Harwon & 45.263 & 41.053 & 13.684 & $\mathrm{~L}$ & 34.035 & 46.807 & 19.158 & $\mathrm{~L}$ \\
\hline 17 & Rwafe Eyswaia & 59.298 & 32.491 & 8.211 & SL & 48.666 & 36.702 & 14.632 & $\mathrm{~L}$ \\
\hline 18 & Awlad Azaz & 86.717 & 8.860 & 4.423 & LS & 85.860 & 8.719 & 5.421 & LS \\
\hline 19 & Kelfao & 57.895 & 29.789 & 12.316 & SL & 52.281 & 31.298 & 16.421 & SL \\
\hline 20 & Arab El Atawla & 57.895 & 21.579 & 20.526 & SCL & 59.299 & 29.754 & 10.947 & SL \\
\hline 21 & Gezert Shandawil & 43.860 & 32.877 & 23.263 & $\mathrm{~L}$ & 55.087 & 20.281 & 24.632 & SCL \\
\hline 22 & Bahta & 43.859 & 34.246 & 21.895 & $\mathrm{~L}$ & 55.088 & 21.649 & 23.263 & SCL \\
\hline 23 & El-Ghrizat & 56.491 & 33.930 & 9.579 & SL & 52.281 & 31.298 & 16.421 & SL \\
\hline 24 & El-Ghrizat & 85.965 & 10.298 & 3.737 & LS & 84.562 & 8.596 & 6.842 & LS \\
\hline 25 & Tunise & 55.088 & 28.491 & 16.421 & SL & 56.491 & 21.614 & 21.895 & SCL \\
\hline 26 & Neida & 83.158 & 11.368 & 5.474 & $\mathrm{LS}$ & 83.158 & 12.737 & 4.105 & LS \\
\hline 27 & Gehina El Sarkia & 55.087 & 36.702 & 8.211 & SL & 56.491 & 31.193 & 12.316 & SL \\
\hline 28 & El-Swamia Shark & 50.877 & 43.649 & 5.474 & SL & 55.087 & 23.018 & 21.895 & SCL \\
\hline 29 & Neg Hermas & 78.948 & 19.684 & 1.368 & LS & 76.141 & 19.754 & 4.105 & SL \\
\hline 30 & El-Sheik Shibl & 49.473 & 38.211 & 12.316 & $\mathrm{~L}$ & 39.649 & 39.825 & 20.526 & $\mathrm{~L}$ \\
\hline 31 & Nazlt Aly & 85.965 & 12.667 & 1.368 & $S$ & 88.772 & 8.491 & 2.737 & S \\
\hline 32 & El-Swamea Gharb & 57.894 & 36.632 & 5.474 & SL & 71.930 & 21.228 & 6.842 & SL \\
\hline 33 & Nazlt Imara & 46.088 & 8.526 & 4.105 & LS & 81.754 & 10.035 & 8.211 & LS \\
\hline 34 & Bin Harb & 57.895 & 35.263 & 6.842 & SL & 59.298 & 31.123 & 9.579 & SL \\
\hline 35 & Um Dona & 57.299 & 33.754 & 8.947 & SL & 56.895 & 30.947 & 12.158 & SL \\
\hline
\end{tabular}

SL: Sandy loam, LS: Loamy sand, CL: Clay loam, SCL: Sandy clay loam SL: Silty Loam, L: Loamy

\section{Results and Discussion}

Studying the changes in the groundwater quality and soil salinity due to the use of this water in irrigation between 1991 (Ghallab, 1995) and 2006 (this study) is very important to reassess the groundwater and surrounding soil quality after 15 years. This comparative study will include the changes in most groundwater properties as well as soil salinity and soil $\mathrm{pH}$.

\section{Groundwater}

\section{- Salinity $\left(\mathbf{E C}_{\mathrm{w}}\right)$}

The results of the groundwater salinity, expressed as electrical conductivity values $\left(\mathrm{EC}_{\mathrm{w}}\right)$ are present in Table 2. Figure 2 shows the changes in the groundwater Salinity $\left(\mathrm{EC}_{\mathrm{w}}\right)$ in Sohag governorate between 1995 and 2006. The groundwater salinity was classified to four classes $(<750,750-2250,2250-5000$ and $>5000$ $\mu \mathrm{S} / \mathrm{cm}$ ) according to the American soil salinity lab (Richards, 1954). The maps of the groundwater salinity in 1991 and 2006 show increase in the $\mathrm{EC}_{\mathrm{w}}$. The first class of groundwater salinity $\left(<750 \mu \mathrm{S} \mathrm{cm}^{-1}\right)$ increased from $9 \%$ in 1991 to $14 \%$ in 2006 . However, the second class $\left(750-2250 \mu \mathrm{S} \mathrm{cm}^{-1}\right)$ decreased from $71 \%$ in 1991 to $46 \%$ in 2006 . The $25 \%$ difference of this groundwater salinity class went to the upper salinity class. Therefore, the third class of groundwater salinity $\left(2250-5000 \mu \mathrm{S} \mathrm{cm}^{-1}\right)$ increased from $17 \%$ in 1991 to $37 \%$ in 2006. Moreover, the last groundwater salinity class $\left(>5000 \mu \mathrm{S} \mathrm{cm}^{-1}\right)$ has the same level as in 1991 . These results ensure increases in the groundwater salinity within these 15 years. . These results agree with those obtained by Bakeer (2008). 
Table 2. Analysis of the groundwater samples of the areas understudy between 1991 and 2006

\begin{tabular}{|c|c|c|c|c|c|c|c|c|c|}
\hline \multirow{2}{*}{ No } & \multirow{2}{*}{ Location } & \multicolumn{2}{|c|}{$\mathrm{EC}_{\mathrm{w}}, \mu \mathrm{S} \mathbf{c m}^{-1}$} & \multicolumn{2}{|c|}{$\mathbf{p H}_{\mathrm{w}}$} & \multicolumn{2}{|c|}{ SAR } & \multicolumn{2}{|c|}{ RSC } \\
\hline & & 1991 & 2006 & 1991 & 2006 & 1991 & 2006 & 1991 & 2006 \\
\hline 1 & El -Balabesh Gobly & 0.84 & 2.84 & 8.44 & 8.22 & 2.08 & 8.45 & 0.84 & 0.00 \\
\hline 2 & El-Ghabat & 1.04 & 1.30 & 7.53 & 8.11 & 2.13 & 0.98 & 0.00 & 0.00 \\
\hline 3 & Awlad Salam Bahre & 1.33 & 1.20 & 7.85 & 8.54 & 2.88 & 3.27 & 0.00 & 0.20 \\
\hline 4 & Naknk & 0.94 & 1.23 & 8.05 & 7.93 & 1.15 & 3.55 & 0.00 & 0.00 \\
\hline 5 & Gazert Naknk & 0.79 & 1.19 & 8.24 & 7.38 & 0.96 & 1.16 & 0.00 & 0.00 \\
\hline 6 & Beat Alam & 7.04 & 8.02 & 7.84 & 8.40 & 13.31 & 13.97 & 0.00 & 0.00 \\
\hline 7 & El-Nosirat & 0.94 & 1.13 & 8.10 & 7.92 & 3.31 & 3.12 & 1.92 & 0.00 \\
\hline 8 & Nego Mazen Shark & 3.37 & 4.04 & 8.39 & 8.59 & 17.28 & 18.52 & 2.94 & 0.00 \\
\hline 9 & Gazert Bardes & 0.90 & 1.55 & 7.92 & 8.42 & 1.43 & 0.77 & 0.00 & 0.20 \\
\hline 10 & Gazert Bardes & 1.02 & 1.58 & 8.06 & 8.50 & 1.72 & 1.00 & 0.00 & 1.00 \\
\hline 11 & Gerga & 1.14 & 0.70 & 8.31 & 8.24 & 2.85 & 3.35 & 0.71 & 3.97 \\
\hline 12 & El-Rakakna & 1.97 & 3.20 & 7.93 & 8.42 & 5.39 & 5.84 & 0.00 & 0.00 \\
\hline 13 & Awlad Hamza & 1.49 & 0.89 & 8.22 & 8.76 & 7.32 & 7.45 & 2.28 & 5.83 \\
\hline 14 & Awlad Salama & 0.68 & 1.01 & 7.97 & 8.83 & 2.43 & 1.07 & 0.00 & 0.00 \\
\hline 15 & El-Zara & 1.11 & 0.97 & $8 . .47$ & 8.49 & 2.37 & 3.77 & 0.00 & 0.03 \\
\hline 16 & Awlad Harwon & 2.05 & 2.94 & 7.45 & 8.08 & 6.51 & 8.54 & 0.00 & 0.00 \\
\hline 17 & Rwafe Eyswaia & 0.89 & 0.60 & 8.46 & 8.34 & 1.29 & 1.60 & 0.77 & 2.30 \\
\hline 18 & Awlad Azaz & 1.87 & 0.92 & 7.88 & 8.27 & 5.48 & 5.17 & 0.00 & 4.03 \\
\hline 19 & Kelfao & 0.91 & 0.62 & 7.99 & 8.56 & 2.08 & 3.83 & 0.43 & 0.97 \\
\hline 20 & Arab El Atawla & 0.84 & 0.57 & 8.17 & 8.23 & 1.01 & 0.91 & 0.00 & 0.03 \\
\hline 21 & Gezert Shandawil & 1.09 & 0.95 & 7.81 & 8.06 & 1.49 & 1.65 & 0.00 & 0.23 \\
\hline 22 & Bahta & 1.28 & 3.19 & 7.83 & 8.25 & 1.53 & 7.91 & 0.00 & 0.10 \\
\hline 23 & El-Ghrizat & 3.16 & 3.24 & 7.87 & 7.96 & 8.74 & 13.38 & 0.00 & 0.00 \\
\hline 24 & El-Ghrizat & 4.91 & 4.41 & 7.97 & 8.16 & 10.82 & 14.32 & 0.00 & 0.00 \\
\hline 25 & Tunise & 1.04 & 0.91 & 8.34 & 7.96 & 2.70 & 7.90 & 0.91 & 5.30 \\
\hline 26 & Neida & 0.94 & 0.73 & 8.05 & 7.48 & 1.33 & 1.48 & 0.00 & 2.50 \\
\hline 27 & Gehina El Sarkia & 1.18 & 1.19 & 7.82 & 8.63 & 2.12 & 0.45 & 0.00 & 0.00 \\
\hline 28 & El-Swamia Shark & 2.58 & 3.20 & 7.71 & 8.28 & 6.31 & 14.48 & 0.00 & 0.00 \\
\hline 29 & Neg Hermas & 3.47 & 4.12 & 7.66 & 8.29 & 9.63 & 6.05 & 0.00 & 0.00 \\
\hline 30 & El-Sheik Shibl & 2.01 & 2.50 & 8.05 & 8.02 & 5.69 & 4.80 & 0.00 & 0.00 \\
\hline 31 & Nazlt Aly & 1.77 & 4.20 & 8.37 & 7.85 & 12.68 & 3.46 & 0.15 & 0.00 \\
\hline 32 & El-Swamea Gharb & 0.73 & 0.98 & 8.36 & 8.10 & 1.63 & 0.43 & 0.02 & 0.00 \\
\hline 33 & Nazlt Imara & 3.18 & 4.30 & 7.27 & 8.17 & 7.25 & 13.12 & 0.00 & 0.00 \\
\hline 34 & Bin Harb & 0.87 & 1.30 & 8.25 & 8.36 & 2.25 & 1.76 & 0.00 & 0.20 \\
\hline 35 & Um Dona & 0.70 & 2.72 & 8.08 & 7.98 & 1.09 & 2.57 & 0.00 & 0.00 \\
\hline
\end{tabular}

1991

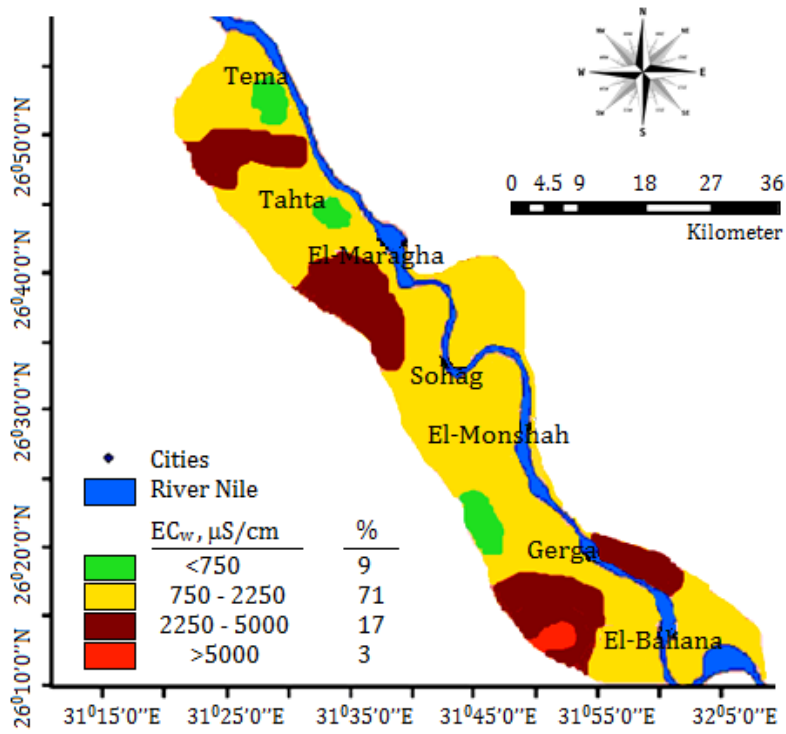

2006

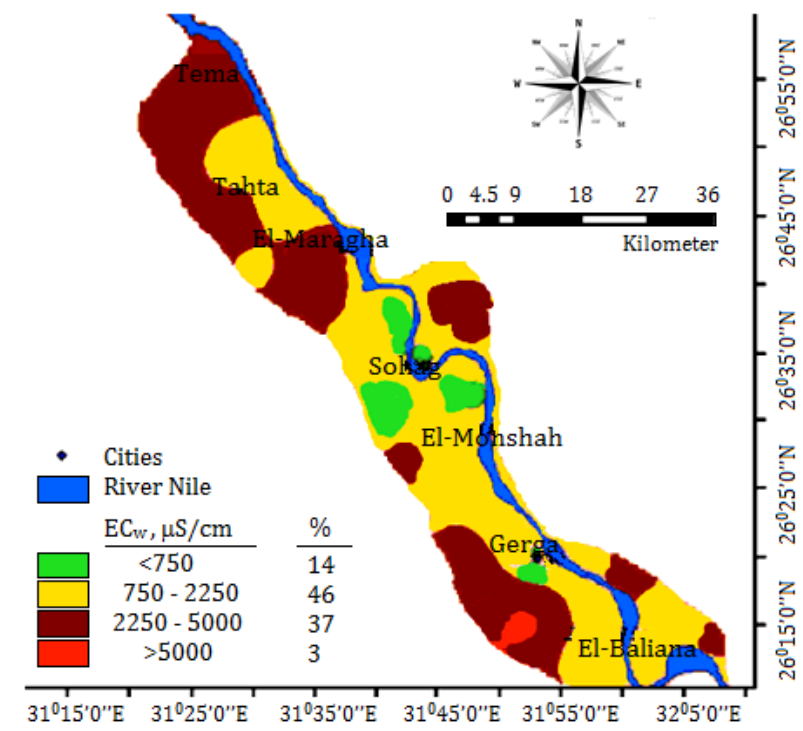

Figure 2 . The changes in the electrical conductivity $\left(\mathrm{EC}_{\mathrm{w}}\right)$ of the groundwater between 1991 and 2006. 


\section{- $\mathbf{p} \mathbf{H}_{\mathbf{w}}$}

The data in Table 2 and $\mathrm{pH}_{\mathrm{w}}$ map of the groundwater (Figure 3) reveal that groundwater $\mathrm{pH}$ has three classes, namely, less than 7.5, 7.5-8.0, and greater than 8.0. The $\mathrm{pH}$ of the first groundwater class has the same level (6\%) as in 1991 but the $\mathrm{pH}$ of the second class (7.5-8.0) decreased from $43 \%$ in 1991 to $17 \%$ in 2006. Also, the third class pH (>8.0) increased from 51\% in 1991 to $77 \%$ in 2006. These changes in the pH classes may be attributed to the changes in the groundwater salt content which is negatively correlated to the pH (El-Dardiry, 2007).

1991

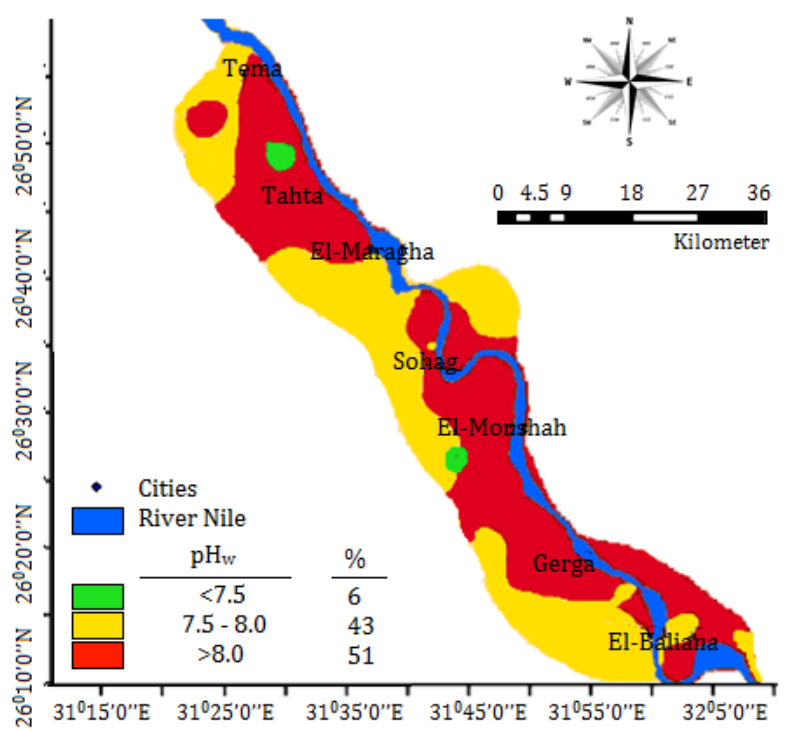

2006

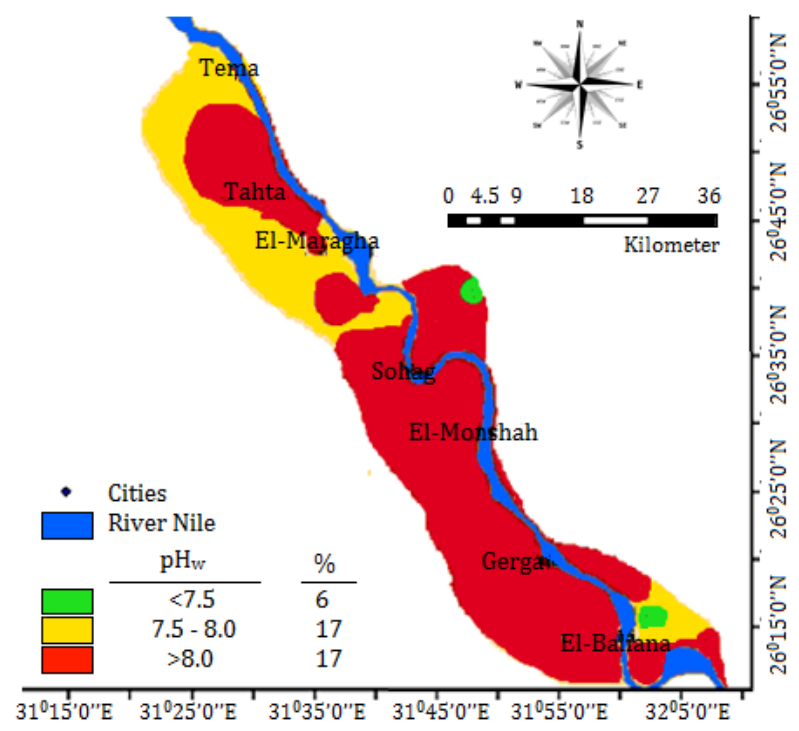

Figure 3. The changes in the groundwater pH between 1991 and 2006.

\section{- Sodium Adsorption Ratio (SAR $)$}

Groundwater SAR of the studied area were classified into two classes namely, 0 to10 and $>10$ (Table 2 and Figure 4). The groundwater SAR of the first class (0-10) decreased from $89 \%$ in 1991 to $83 \%$ in 2006 but it's the second class (> 10) increased from $11 \%$ in 1991 to $17 \%$ in 2006 (Labeeb, 2002).

1991

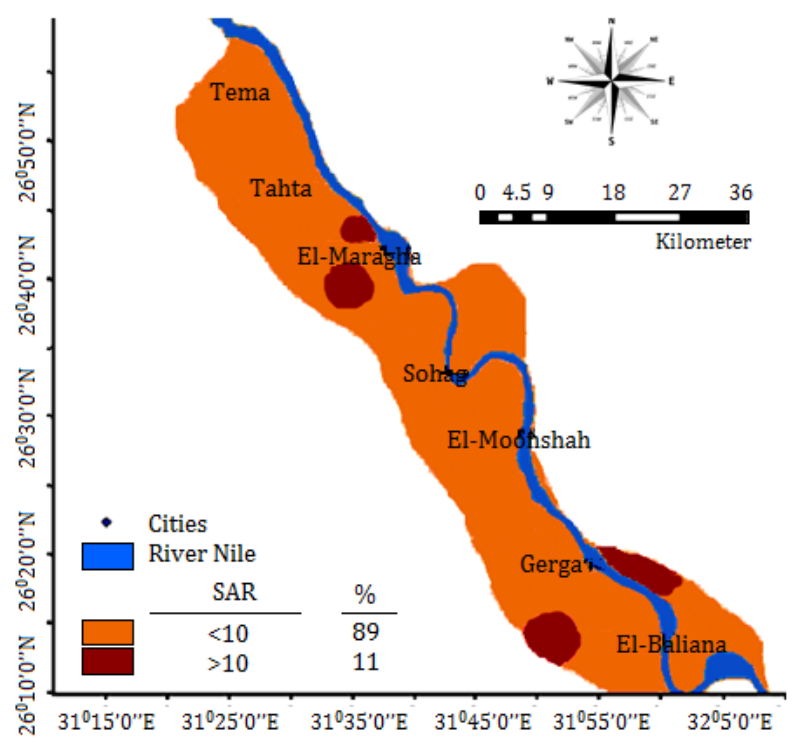

2006

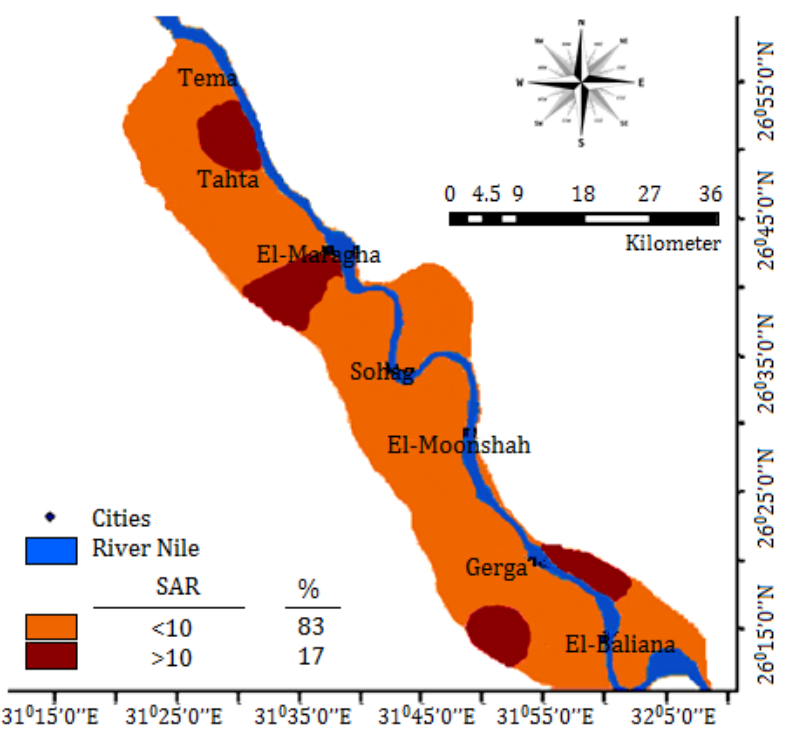

Figure 4. The changes in the sodium adsorption ratio (SAR) of the groundwater between 1991 and 2006.

\section{- Residual Sodium Carbonate $\left(\mathrm{RSC}_{\mathrm{w}}\right.$ )}

RSC of groundwater samples were classified into three classes, namely, less than $1.25,1.25$ to 2.50 , and greater than $2.50 \mathrm{meq} / \mathrm{l}$ (Table 2 and Figure 5). The maps showed that the first and third classes of $\mathrm{RSC}_{\mathrm{w}}$ changed from 91 and $3 \%$, respectively, in 1991 to 83 and 11\%, respectively, in 2006. The second class (1.25 
$-2.5 \mathrm{meq} / \mathrm{l})$ showed the same level of $6 \%$ in 1991 and 2006. The increase in the high groundwater class of RSC may limit the use of this water in irrigation. If the RSC is greater than $2.5 \mathrm{meq} / \mathrm{l}$, the water will not be appropriate for irrigation. High sodium ions in water affect the permeability of soil and cause infiltration problems. This is because the exchangeable sodium on soil clays can replace the adsorbed calcium and magnesium on these clays and cause the dispersion of soil particles. The increase in the RSC of irrigation water is attributed to the increases in salinity $\left(\mathrm{EC}_{\mathrm{e}}\right)$ and SAR of the soil.

1991

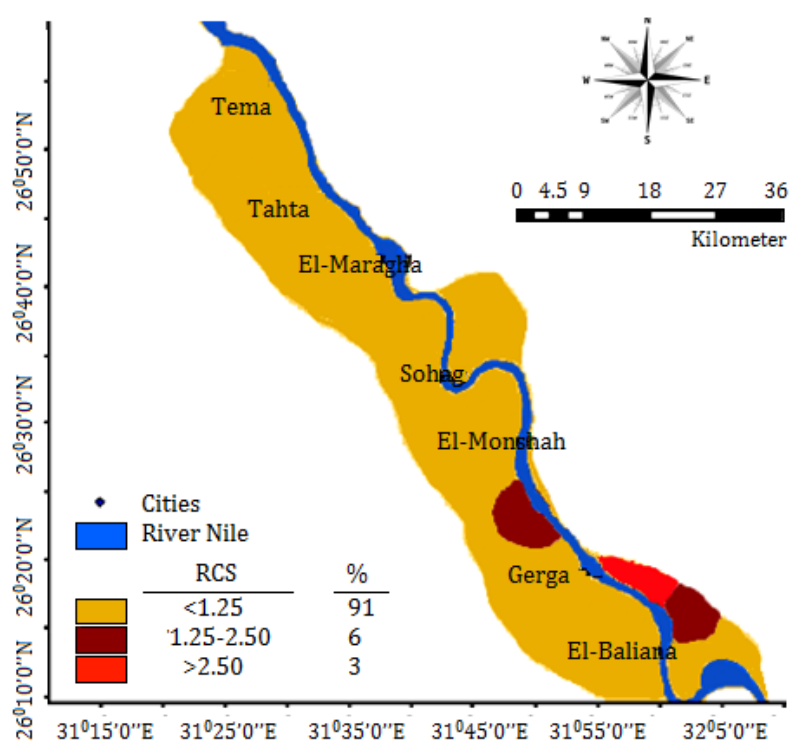

2006

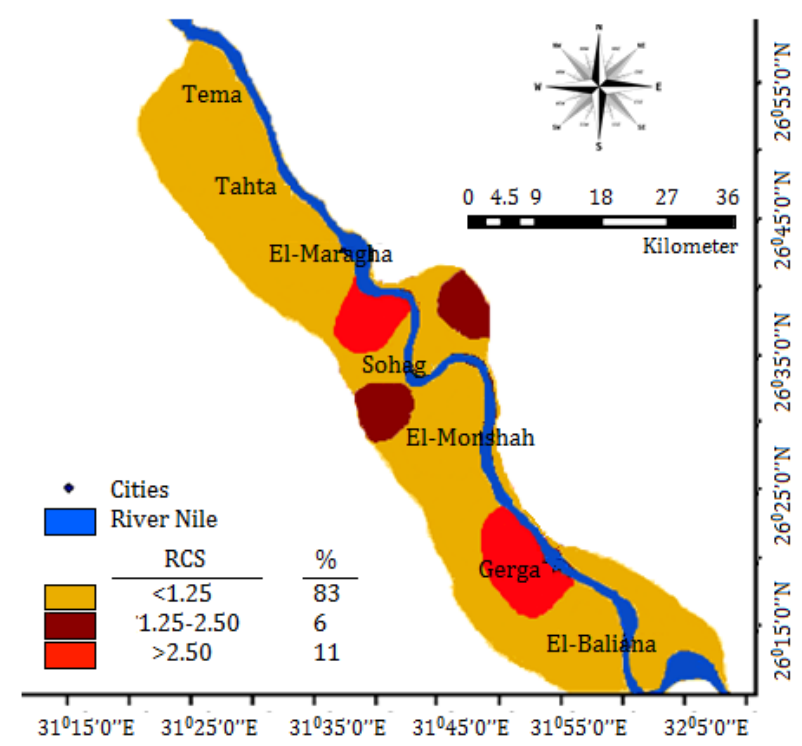

Figure 5. The changes in the residual sodium carbonate (RSC) of the groundwater between 1991 and 2006.

\section{- Soluble Cation Changes}

Table 3 reveals that the major ions in groundwater samples are sodium, calcium and magnesium. The mean value of the sodium in the groundwater increased from $8.18 \mathrm{meq} / \mathrm{l}$ in 1991 to $11.95 \mathrm{meq} / \mathrm{l} \mathrm{in} 2006$. The increase in sodium concentration matches the changes in the $\mathrm{EC}_{\mathrm{w}}$. The mean calcium ions in the groundwater increased from $1.57 \mathrm{meq} / \mathrm{l}$ in 1991 to 4.65 in 2006. The mean groundwater magnesium also increased from $4.41 \mathrm{meq} / \mathrm{l}$ in 1991 to $4.74 \mathrm{meq} / \mathrm{l}$ in 2006.

\section{- Soluble Anion Changes}

Chloride, sulfate, carbonate and bicarbonate ions are the main anions in groundwater (Table 3). The average groundwater chloride generally increased from $6.59 \mathrm{meq} / \mathrm{l}$ in 1991 to $7.23 \mathrm{meq} / \mathrm{l}$ in 2006 . The increase in the groundwater chloride was consistent with that of the $\mathrm{EC}_{\mathrm{w}}$ and $\mathrm{Na}$. The mean sulphate ions in the groundwater were doubled from $3.94 \mathrm{meq} / \mathrm{l}$ in 1991 to $7.07 \mathrm{meq} / \mathrm{l}$ in 2006. However, average concentrations of $\mathrm{CO}_{3}=+\mathrm{HCO}_{3}$ - ions in the groundwater increased from $3.69 \mathrm{meq} / \mathrm{l}$ in 1991 to $6.12 \mathrm{meq} / \mathrm{l}$ in 2006.

\section{Soils}

\section{- Soil Salinity}

Various analyses in Table 4 indicate that the soil salinity increased from 1991 to 2006 . The salinity maps of surface and subsurface soils (Figures 6 and 7, respectively) show an increase trend in the soil salinity from 1991 to 2006 . The salinity class of $<0.05 \%$ for the surface soils increased from $69 \%$ in 1991 to $77 \%$ in 2006. However, the salinity class of $0.05-0.10 \%$ salts approximately appears to have the same level $(17 \%)$ in 1991 and 2006. Also, the class of $0.10-0.15 \%$ salts decreased from $11 \%$ in 1991 to $3 \%$ in 2006 . The worse soil salinity class of $>0.15 \%$ has been the same percentage (3\%) in 1991 and 2006. The results reveal that the salinity of the surface soils decreased from 1991 to 2006 in some classes. This may indicate that the salts were leached from surface layer to subsurface one. The percentage of the $0.05-0.10 \%$ salinity class of subsurface layers decreased from $37 \%$ in 1991 to $28 \%$ in 2006 . Also, the class containing $0.10-0.15 \%$ salts decreased from $23 \%$ in 1991 to $15 \%$ in 2006. However, the class of $0.15-0.20 \%$ salts increased from $11 \%$ in 1991 to $14 \%$ in 2006. The worse soil salinity class of $>0.20$ salts ascended from $29 \%$ in 1991 to $43 \%$ in 2006. These results reveal that the soil salinity increased with depth from 1991 to 2006 . This may be due to the leaching processes. 


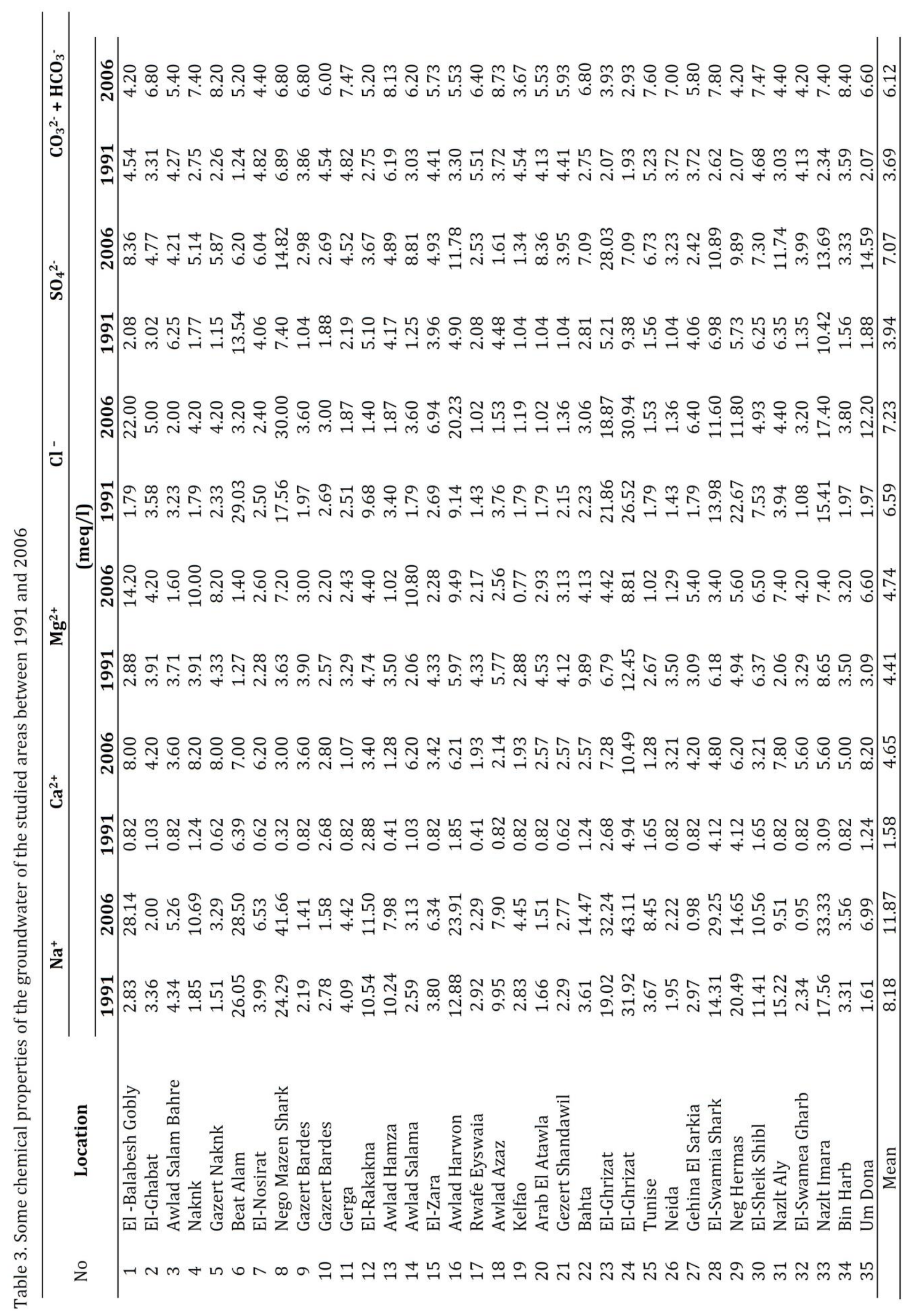


Table 4. Analysis of the soil samples of the area understudy between 1991 and 2006

\begin{tabular}{|c|c|c|c|c|c|c|c|c|c|}
\hline \multirow{3}{*}{ No } & \multirow{3}{*}{ Location } & \multicolumn{4}{|c|}{ Salts, $\%$} & \multicolumn{4}{|c|}{$\mathrm{pH}_{\mathrm{e}}$} \\
\hline & & \multicolumn{2}{|c|}{1991} & \multicolumn{2}{|c|}{2006} & \multicolumn{2}{|c|}{1991} & \multicolumn{2}{|c|}{2006} \\
\hline & & Surface & $\begin{array}{c}\text { Sub- } \\
\text { surface }\end{array}$ & Surface & $\begin{array}{c}\text { Sub- } \\
\text { surface }\end{array}$ & Surface & $\begin{array}{c}\text { Sub- } \\
\text { surface }\end{array}$ & Surface & $\begin{array}{c}\text { Sub- } \\
\text { surface }\end{array}$ \\
\hline 1 & El -Balabesh Gobly & 0.04 & 0.08 & 0.03 & 0.31 & 7.69 & 8.21 & 7.95 & 8.60 \\
\hline 2 & El-Ghabat & 0.04 & 0.06 & 0.03 & 0.06 & 7.96 & 8.70 & 7.85 & 8.75 \\
\hline 3 & Awlad Salam Bahre & 0.04 & 0.07 & 0.04 & 0.09 & 7.94 & 8.60 & 7.84 & 8.50 \\
\hline 4 & Naknk & 0.03 & 0.18 & 0.02 & 0.27 & 7.75 & 8.15 & 7.75 & 8.35 \\
\hline 5 & Gazert Naknk & 0.06 & 0.27 & 0.04 & 0.32 & 7.94 & 8.18 & 7.72 & 8.10 \\
\hline 6 & Beat Alam & 0.04 & 0.07 & 0.03 & 0.08 & 8.20 & 8.60 & 8.50 & 8.30 \\
\hline 7 & El-Nosirat & 0.06 & 0.07 & 0.03 & 0.13 & 7.74 & 7.82 & 7.95 & 8.26 \\
\hline 8 & Nego Mazen Shark & 0.12 & 0.29 & 0.08 & 0.31 & 7.90 & 8.60 & 8.15 & 8.60 \\
\hline 9 & Gazert Bardes & 0.02 & 0.10 & 0.03 & 0.09 & 7.80 & 8.50 & 7.74 & 8.45 \\
\hline 10 & Gazert Bardes & 0.02 & 0.07 & 0.02 & 0.09 & 7.75 & 8.44 & 7.84 & 8.30 \\
\hline 11 & Gerga & 0.04 & 0.10 & 0.03 & 0.71 & 8.10 & 8.70 & 8.00 & 8.00 \\
\hline 12 & El-Rakakna & 0.04 & 0.12 & 0.03 & 0.17 & 7.83 & 8.71 & 7.75 & 8.50 \\
\hline 13 & Awlad Hamza & 0.11 & 0.14 & 0.13 & 0.14 & 7.95 & 9.30 & 8.16 & 9.60 \\
\hline 14 & Awlad Salama & 0.03 & 0.09 & 0.02 & 0.09 & 7.95 & 8.86 & 7.77 & 8.71 \\
\hline 15 & El-Zara & 0.04 & 0.14 & 0.04 & 0.37 & 8.05 & 8.90 & 8.00 & 8.20 \\
\hline 16 & Awlad Harwon & 0.04 & 0.60 & 0.05 & 0.16 & 7.90 & 8.44 & 7.75 & 9.20 \\
\hline 17 & Rwafe Eyswaia & 0.04 & 0.66 & 0.02 & 0.45 & 7.74 & 8.20 & 7.82 & 8.10 \\
\hline 18 & Awlad Azaz & 0.15 & 0.08 & 0.27 & 0.21 & 8.01 & 8.99 & 8.95 & 9.25 \\
\hline 19 & Kelfao & 0.02 & 0.19 & 0.02 & 0.20 & 8.06 & 8.35 & 7.75 & 8.30 \\
\hline 20 & Arab El Atawla & 0.02 & 0.15 & 0.02 & 0.22 & 7.85 & 9.50 & 7.69 & 9.10 \\
\hline 21 & Gezert Shandawil & 0.02 & 0.25 & 0.02 & 0.50 & 7.75 & 8.16 & 7.70 & 7.98 \\
\hline 22 & Bahta & 0.05 & 0.34 & 0.06 & 0.40 & 7.95 & 8.20 & 7.91 & 8.25 \\
\hline 23 & El-Ghrizat & 0.03 & 0.12 & 0.04 & 0.16 & 7.82 & 8.52 & 8.06 & 8.75 \\
\hline 24 & El-Ghrizat & 0.02 & 0.05 & 0.01 & 0.12 & 8.50 & 8.55 & 8.50 & 8.72 \\
\hline 25 & Tunise & 0.02 & 0.25 & 0.02 & 0.45 & 7.65 & 8.22 & 8.10 & 7.95 \\
\hline 26 & Neida & 0.02 & 0.10 & 0.02 & 0.10 & 7.91 & 8.33 & 8.15 & 8.50 \\
\hline 27 & Gehina El Sarkia & 0.03 & 0.09 & 0.04 & 0.07 & 7.80 & 8.41 & 8.54 & 8.70 \\
\hline 28 & El-Swamia Shark & 0.03 & 0.09 & 0.02 & 0.09 & 7.74 & 8.38 & 8.00 & 8.35 \\
\hline 29 & Neg Hermas & 0.16 & 0.14 & 0.07 & 0.13 & 7.75 & 8.75 & 7.90 & 8.82 \\
\hline 30 & El-Sheik Shibl & 0.05 & 0.21 & 0.07 & 0.27 & 7.65 & 8.10 & 7.75 & 8.19 \\
\hline 31 & Nazlt Aly & 0.05 & 0.30 & 0.04 & 0.36 & 8.10 & 8.05 & 8.30 & 8.00 \\
\hline 32 & El-Swamea Gharb & 0.02 & 0.08 & 0.06 & 0.07 & 7.82 & 8.45 & 7.63 & 8.35 \\
\hline 33 & Nazlt Imara & 0.02 & 0.30 & 0.02 & 0.07 & 8.12 & 8.10 & 8.35 & 8.10 \\
\hline 34 & Bin Harb & 0.05 & 0.08 & 0.04 & 0.23 & 7.82 & 8.58 & 7.90 & 8.19 \\
\hline 35 & Um Dona & 0.14 & 0.19 & 0.04 & 0.17 & 7.78 & 8.64 & 7.78 & 8.16 \\
\hline
\end{tabular}
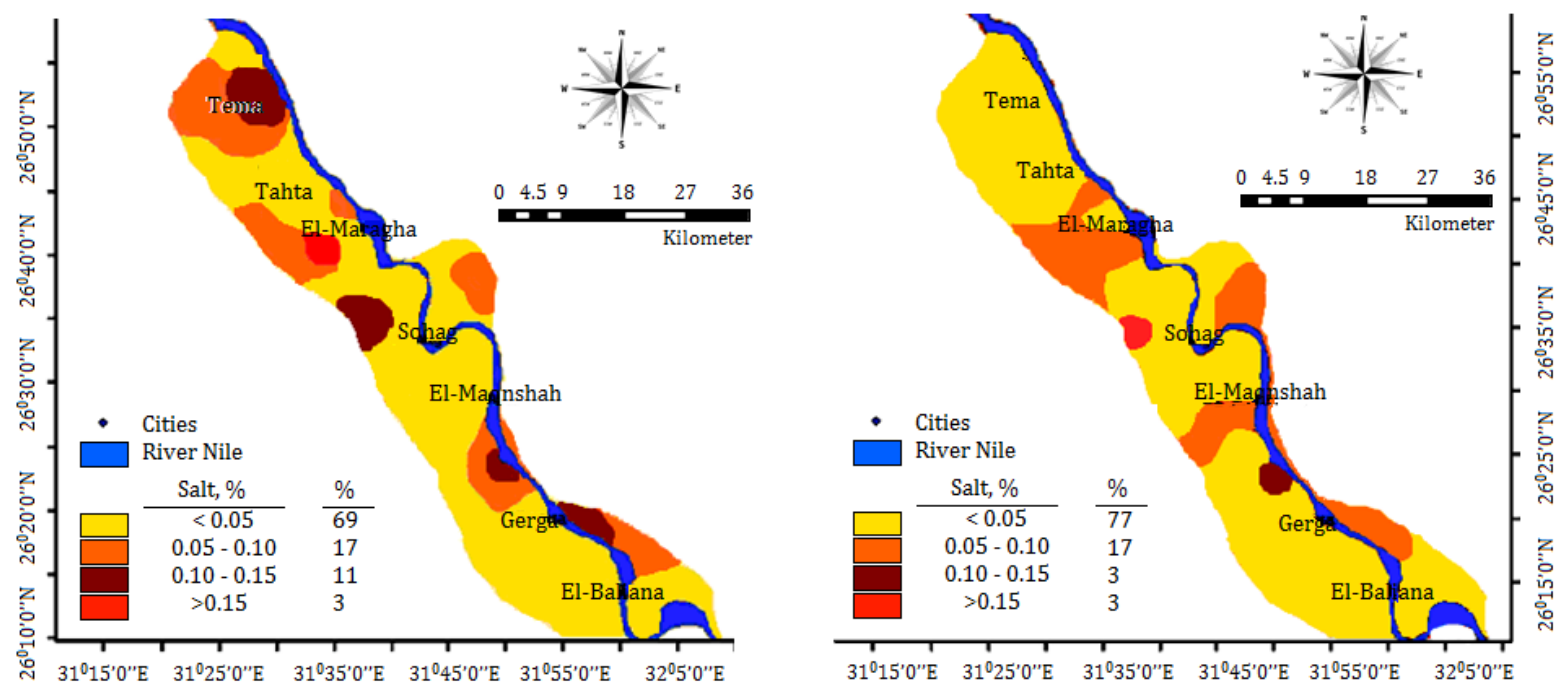

Figure 6. The changes in salt concentration of surface soil samples $(0-25 \mathrm{~cm})$ irrigated by groundwater between 1991 and 2006. 
1991

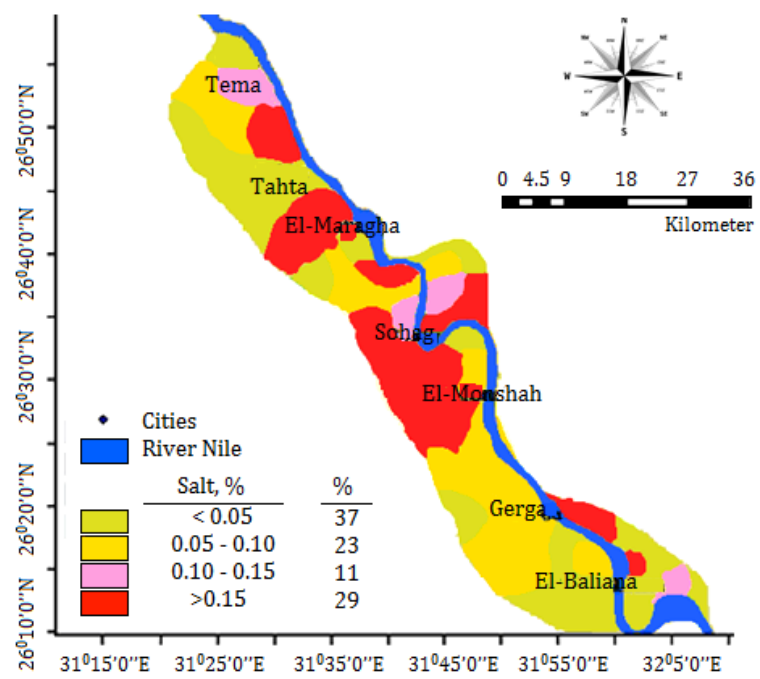

2006

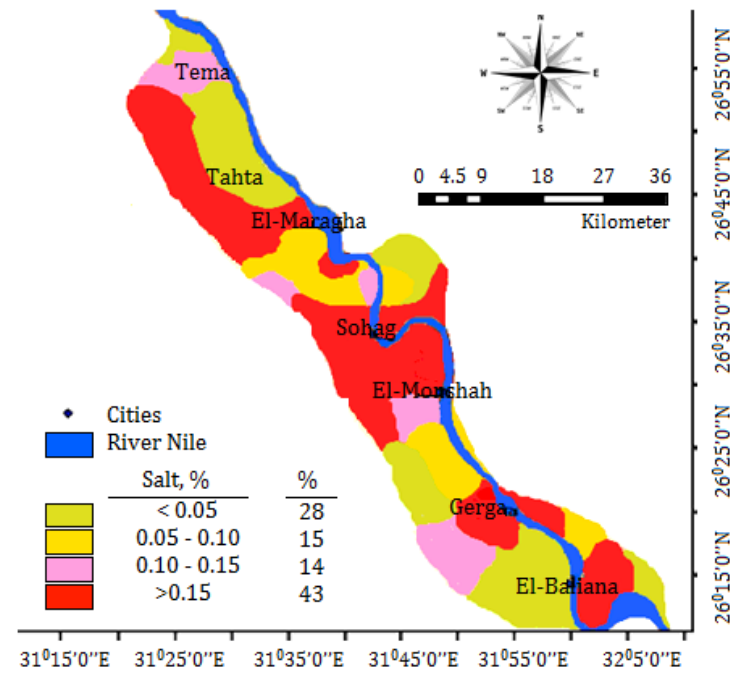

Figure 7. The changes in salt concentration of subsurface soil samples $(25-50 \mathrm{~cm})$ irrigated by groundwater between 1991 and 2006.

It is clear that the future of Sohag soils irrigated with groundwater is of a great danger at most measures. The overall view of the salinity indicates a shift toward the salinization of the groundwater and soils irrigated with these waters. The excess of salt content is one of the major concerns with water used for irrigation. A high salt concentration in the water and soil negatively affects the crop yields, degrade the land and pollute the groundwater. These results agree with those obtained by Ghallab and Ali (2000).

\section{- Soil pH}

The $\mathrm{pH}$ of the soil samples (Table 4, Figures 8, 9) was classified into two classes, namely less than 8.0 and greater than 8.0 according to Ghallab (1995). The percentage of surface soil samples of the first class ( $\mathrm{pH}<$ 8.0) decreased from $77 \%$ in 1991 to $60 \%$ in 2006. However, the second pH class (> 8) increased from $23 \%$ in 1991 to $40 \%$ in 2006. The first pH class (<8) of the subsurface layers increased from $3 \%$ in 1991 to $6 \%$ in 2006. However, the percentage of subsurface soil samples having pH range between 8.0 and 8.5 increased from $51 \%$ in 1991 to $60 \%$ in 2006 . However, subsurface soil pH having > 8 decreased from $46 \%$ in 1991 to $34 \%$ in 2006 . These changes in the soil pH may be related to the changes in the salt content.
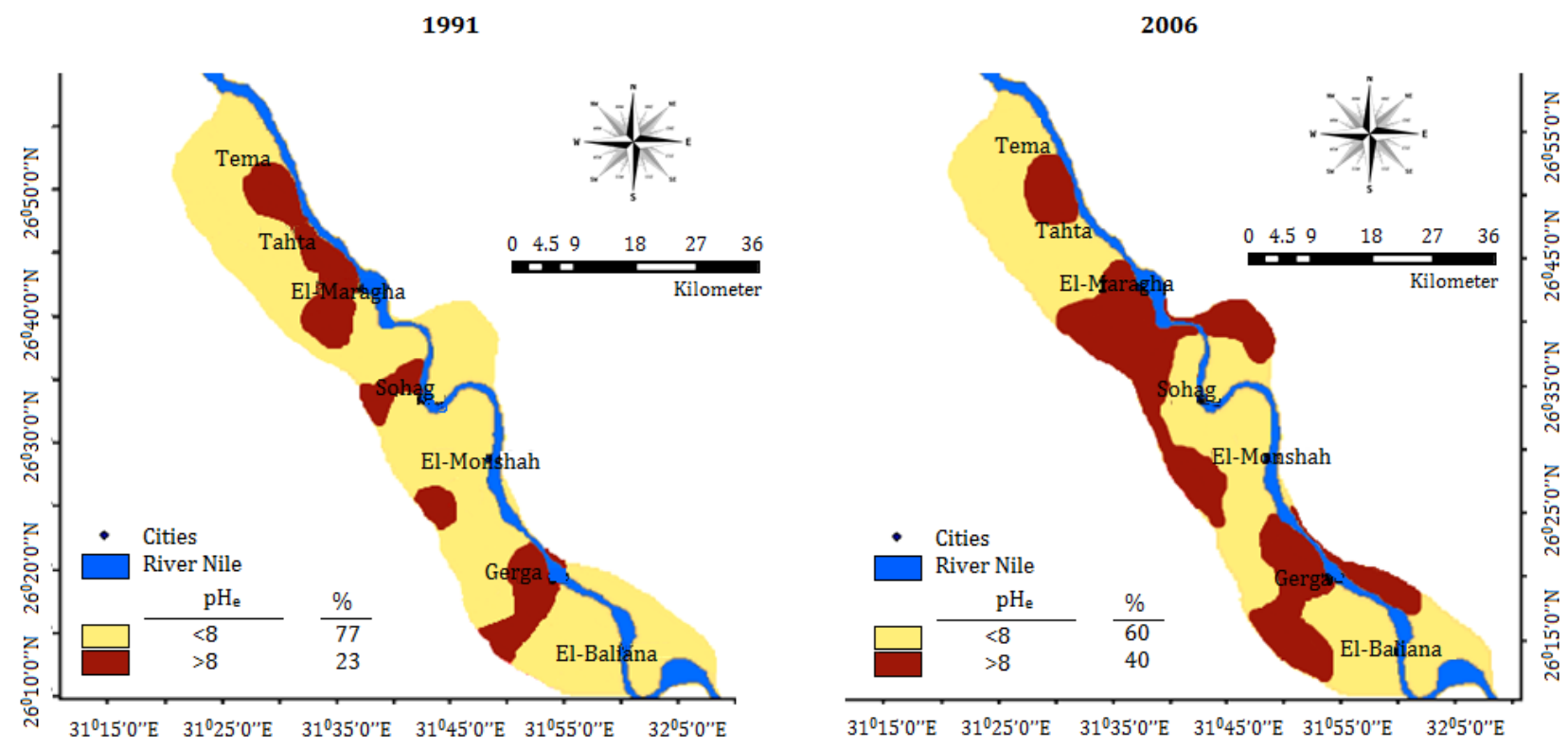

Figure 8. The changes in the pH of surface soil samples $(0-25 \mathrm{~cm})$ irrigated by groundwater between 1991 and 2006. 
1991

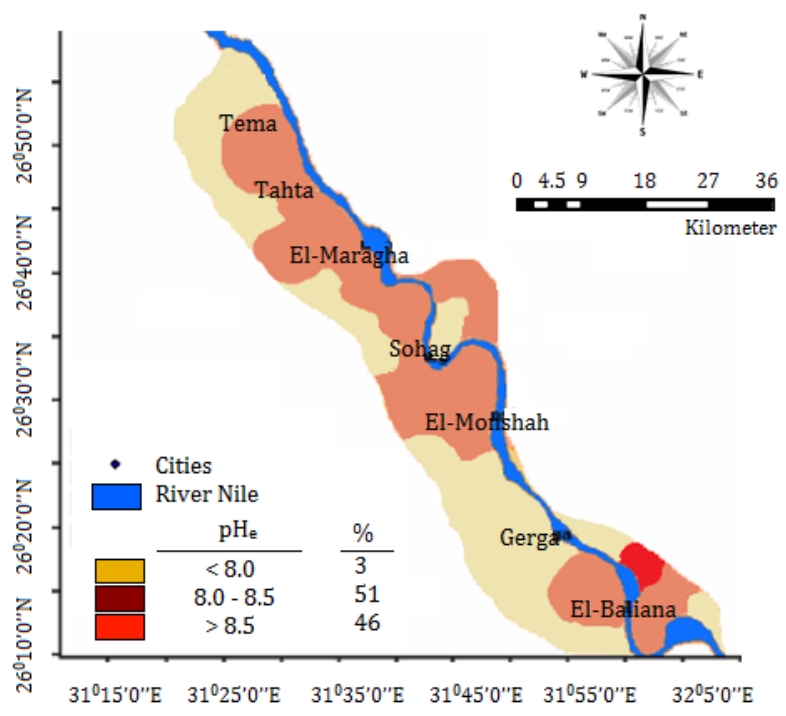

2006

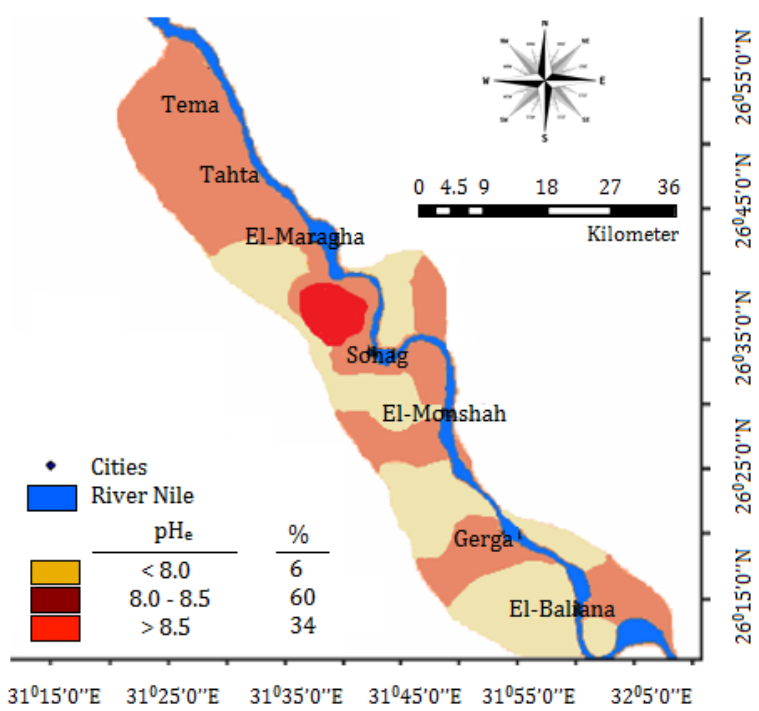

Figure 9. The changes in the pH of subsurface soil samples $(25-50 \mathrm{~cm})$ irrigated by groundwater between 1991 and 2006.

\section{Conclusion}

The increase of salinity in the groundwater and soil from 1991 to 2006 is certain. Soils with a moderate content of salts can be used if a moderate leaching occurs. Water with high salinity and sodium (SAR) should not be used for water irrigation. However, in some places with water shortage, water with high salinity can be used as a supplement for other sources and with a good management and a control of salinity. If water with a very high salinity is used, a drainage system must be installed to overcome the soil salinity problem that is caused by using saline groundwater in irrigation. Moreover, drainage must be adequate and water must be applied in excess to provide considerable leaching. Amelioration of these soils needs a source of calcium $\left(\mathrm{Ca}^{2+}\right)$ that can replace the excess exchangeable sodium $\left(\mathrm{Na}^{+}\right)$. Additions of gypsum may help to ameliorate such soils to supply adequate $\mathrm{Ca}^{2+}$ and growing of certain crops that are tolerant to ambient soil salinity and sodicity. Further research will be carried out to determine the change in soil and groundwater properties over the next 15 years. Monitoring soil salinity, as well as, periodic analysis of soils and groundwater wells to determine the changes taking place in the salinity and other properties is recommended.

\section{References}

Albaji, M., Nasab, B. S., Kashkoli, HA., Naseri. A., 2010. Comparison of different irrigation methods based on the parametric evaluation approach in the plain West of Shush, Iran. Irrigation and Drainage 59(5): 547-558.

Al-Khaier, F., 2003. Soil salinity detection using satellite remote sensing. Ms.C.Thesis. International Institute For GeoInformation Science and Earth Observation, Enschede, The Netherlands. Available at [access date: 11.12.2017]: http://www.itc.eu/library/Papers_2003/msc/wrem/khaier.pdf

Bakeer, I.H.I., 2008. Using Geographic Information System (GIS) in reassessment of soil and groundwater salinity of Sohag Soils. Ms.C.Thesis. Assiut University, Faculty of Agriculture, Department of Soil and Water, Assiut, Egypt. [in Arabic]. Available at [access date: 11.12.2017]: http://www.alwelaie.com/website/universitytheses_details_print.php?theses_id=2295

El-Dardiry, E.I., 2007. Soil available water as affected by some soil physico-chemical properties in salt affected soils. Australian Journal of Basic and Applied Sciences 1(3): 220-225

Ghabour, Th.K., Daels, L., 1993. Mapping and monitoring of soil salinity of El- Fayoum depression by the aid of land sat imagery. Egypian Journal of Soil Science 33(4): 355-370.

Ghallab, A., Ali, A. M., 2000. Remote sensing and GIS approach for environmental changes monitoring and evaluation: A case study of Assiut Governorate, Egypt. Assiut Journal of Agricultural Sciences 31(2): 1-13.

Ghallab, A., 1995. Management of saline underground water for irrigation in upper Egypt. Ph.D. Thesis. Assiut University, Faculty of Agriculture, Department of Soil and Water, Assiut, Egypt. [in Arabic]. Available at [access date: 11.12.2017]: http://www.aun.edu.eg/thesis_files/5018.pdf 
Hillel, D., 2000. Salinity management for sustainable agriculture: Integrating science, environment, and economics. World Bank Publications. Washington DC, USA. 98p.

Ismail, M., Yacoub R. K., 2012. Digital soil map using the capability of new technology in Sugar Beet area, Nubariya, Egypt. The Egyptian Journal of Remote Sensing and Space Sciences 15(2): 113-124.

Jackson, M.L. 1967. Soil chemical analysis. Prentice Hall of India Pvt. Ltd. New Delhi, India. 498p.

Jackson, M.L. 1969. Soil chemical analysis: Advanced course. A manual of methods useful for instruction and research in soil chemistry, physical chemistry of soils, soil fertility, and soil genesis. Cornell University, USA. 895p.

Labeeb, G., 2002. Effect of irrigation water having different EC and SAR values on onion productivity under sandy soil conditions. Journal of Agricultural Science-Mansoura University 27(9): 6505-6522.

McLean, E.O., 1982. Soil pH and lime requirement. In: Methods of Soil Analysis, Part 2, Chemical and microbiological properties, Second Edition. Number 9, Page, A.L., Keeney, D. R., Baker, D.E., Miller, R.H., Ellis, R. Jr., Rhoades, J.D. (Eds.). ASA-SSSA, Madison, Wisconsin, USA. pp.199-224.

Nelson, R.E., 1982. Carbonate and gypsum. In: Methods of Soil Analysis, Part 2, Chemical and microbiological properties, Second Edition. Number 9, Page, A.L., Keeney, D. R., Baker, D.E., Miller, R.H., Ellis, R. Jr., Rhoades, J.D. (Eds.). ASASSSA, Madison, Wisconsin, USA. pp. 181-198.

Page, A. L., Miller R. H., Keeney D. R., 1986. Methods of Soil Analysis. Part 2. Physical and Mineralogical properties. 2nd edition. Soil Science Society of America Journal, Madison, Wisconsin, USA.

Qadir, M., Ghafoor, A., Murtaza, G., 2001. Use of saline-sodic waters through phytoremediation of calcareous salinesodic soils. Agricultural Water Management 50(3): 197- 210.

Rhoades, J.D., 1982. Soluble salts. In: Methods of Soil Analysis Part 2, Chemical and Microbiological Properties. Second Edition. Number 9, Page, A.L., Keeney, D. R., Baker, D.E., Miller, R.H., Ellis, R. Jr., Rhoades, J.D. (Eds.). ASA-SSSA, Madison, Wisconsin, USA. pp.167-180.

Richards, L.A., 1954. Diagnosis and improvement of saline and alkali soil. U.S. Salinity Lab. Staff, U.S. Department of Agriculture, Agricultural Research Service, HandBook 60. Washington D.C. USA. 160p.

Sayed, A.S.A. 2013. Evaluation of the Land Resources for Agricultural Development - case study: El-Hammam Canal and its Extension, NW Coast of Egypt. Ph.D. Thesis, Department Geowissenschaften, Universität Hamburg. Germany. Available at [access date: 11.12.2017]: http://www.secheresse.info/spip.php?article26227

Yunus, M.A.J., Nakagoshi, N., Ibrahim, A., 2003. Application of GIS and remote sensing for measuring and evaluating land-use change and its impact on water quality in the Pinang River watershed. Ecology and Civil Engineering 6(1): 97-110. 